\title{
EDITORIAL
}

\section{Climate change in the Maritimes - concerns and challenges}

Global climate change is accepted now as a fact by the scientific community, as well as by other informed groups in society. The evidence is overwhelming. Five assessments from the IPCC (the Intergovernmental Panel on Climate Change) indicate a rapidly warming planet, outside of historic limits, that is driven by the increased concentration of $\mathrm{CO}_{2}$ in the atmosphere now over $400 \mathrm{ppm}$. This issue of the PNSIS has two articles on the topic, one by Charles Schafer, formerly at the Bedford Institute of Oceanography, and a second by David Garbary of St. Francis Xavier University. The first paper discusses historical warmer climatic periods that the earth has endured; the second describes a practical way of teaching about climate change. The reader is implored to read these articles carefully as they present different perspectives and draw attention to this pivotal environmental and social challenge of our time and one with great consequences for the Maritimes.

Society faces many climate-change related events which are becoming well documented. They include: sea-level rise and the increased height of storm surges; more fierce storms (such as one just experienced in January 2018, with wind gusts of over $200 \mathrm{~km} /$ hr); increased coastal erosion, aggravated by the storms and higher sea levels; increased water temperatures in the North Atlantic, both at surface and in places, such as the Gulf of Maine, at depth; acidification of the ocean, with $\mathrm{pH}$ dropping by 0.1 units $(30 \%)$; changing distribution of various species (invertebrates, fish, birds, marine mammals), linked to changing water temperatures and food availability; and the prospect of hotter and drier summers on land, with implications (positive and negative) for agriculture and forestry.

The causes and the impact of climate change are highly complex. Indeed, understanding it is the number one problem of ecology, environmental science, atmospheric science, and oceanography. It also involves a consideration of both complexity theory and Gaia theory. The latter considers the earth to be a self-regulating system in a state of homeostasis, a global example of symbiosis (see book review of One Plus One Equals One in this issue, and articles and books by Lynn Margulis, James Lovelock, and Stephen Lewis). 
For Atlantic science, the challenges posed by global climate change are many and surviving them requires science, adaptation, mitigation, and public education. Continued research is needed on the possible impacts of changing temperature regimes and ocean acidification on species of economic importance, e.g., fisheries species such a cod, haddock and lobsters. Research is also required to understand the physical and chemical processes that drive climate change and affect the seas of the NW Atlantic, and the adjacent land. This should involve obtaining long-term data sets by monitoring and measuring key variables associated with the weather, climate, and the water column. Research should also continue on approaches for mitigation and adaptation. What can be done or should be done? Can we reduce $\mathrm{CO}_{2}$ emissions and eliminate the use of coal? And what should not be done? It can be argued that armouring shorelines or constructing houses and roads close to cliff tops and on top of barrier beaches should no longer be allowed. There is an urgent need for more public and political education on this issue, but it should be solution-based, not apocalyptic. Education should focus on what we, as individuals and collectively as a society, can do to reduce our carbon footprint (for example, for related marine conservation initiatives, see www.bridge.ocean.org).

The NSIS has an important role to play in this challenge. We can continue to be a conduit for information through talks and this publication; to fund student research projects; and to encourage the membership to be involved in the various local and regional initiatives. These include improving public transportation, reducing our use and dependence on fossil fuels, and encouraging greater appropriate protection for our coastlines and coastal habitats.

Rapid climate change is upon us; the time for effective action is now to ensure a liveable planet for future generations. Further suggestions from all NSIS members and our other readers are encouraged.

\section{REFERENCES}

Garbary, D. (2018). This volume.

IPCC (Intergovernmental Panel on Climate Change). 2014. IPCC Fifth Assessment Report (AR5). Cambridge University Press, Cambridge, UK. 169 p.

Lewis, S. (1974). The world's biggest membrane. Ch. 29 in: The Lives of a Cell. Notes of a Biology Watcher. Bantam Books Inc. Toronto. 180 p. 
Lovelock, J. E. (1979). A New Look at Life on Earth. Oxford University Press, Oxford, UK. 157 p.

Lovelock, J.E. and Margulis, L. (1974). Atmospheric homeostasis by and for the biosphere: the Gaia hypothesis. Tellus 24: 2-9.

Schafer, C. (2018). This volume.

P.G. Wells, Dalhousie University, Editor, PNSIS

D.H. Richardson, Saint Mary's University, Assoc. Editor, PNSIS 
